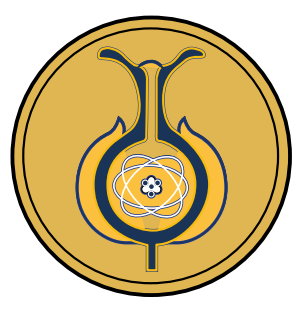

\title{
Mathematical Creative Thinking Ability and Self-Efficacy: A Mixed-Methods Study involving Indonesian Students
}

\author{
Fuentes de pensamiento creativo y autoeficacia en estudiantes de Indonesia: \\ Un estudio de métodos mixtos \\ Fontes de pensamento criativo e autoeficácia em estudantes indonésios: um \\ estudo de métodos mistos
}

Sri Rahyuningsih ${ }^{1}$, Muhammad Nurhusain ${ }^{2}$, Nenny Indrawati $^{3}$

Received: Apr/6/2021 • Accepted: Dec/12/2021 • Published: Feb/14/2022

\section{Abstract (iD)}

With regard to creativity in mathematics, scholars tend to focus on the logical realm, which includes fluency, flexibility, and originality while overlooking the value of the affective domain, which includes self-efficacy, beliefs, and attitudes. The objectives of this study were 1) to investigate the extent to which self-efficacy affects students' mathematical creative thinking ability; and 2) to determine the characteristics of students with high mathematical creative thinking ability and high self-efficacy. A mixed-method approach, that combined semi-structured interviews, and correlation analysis was employed to investigate the effect of self-efficacy on students' mathematical creative thinking ability. The participants of the study were selected from junior high schools (JHS) in the city of Makassar. Ninety-six students (42 boys and 54 girls, aged 14 years old) completed a questionnaire assessing their mathematics self-efficacy. In general, the results proved that self-efficacy had an effect on JHS students' mathematical creative thinking ability. This study also revealed that students with high self-efficacy are more likely to possess high mathematical creative thinking ability and vice versa. The characteristics of students with high mathematical creative thinking ability and high self-efficacy include excessive anxiety, reliance on key experiences, such as the ability to generate ideas (cognitive novelty), the ability to propose various solutions (cognitive variety), and the ability to change perceptions (cognitive framing).

Keywords: mathematical; creative thinking ability; self-efficacy; cognitive novelty; cognitive variety; cognitive framing.

\section{Resumen (10)}

Cuando se trata de creatividad en matemáticas, los grupos académicos tienden a enfocarse en el ámbito lógico, que incluye fluidez, flexibilidad y originalidad mientras pasan por alto el valor del ámbito afectivo,

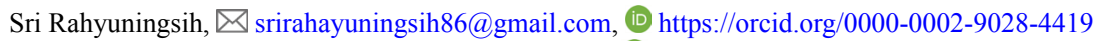

Muhammad Nurhusain, \zein.alhusain@gmail.com, (10 https://orcid.org/0000-0001-9128-9097

Nenny Indrawati, $\bowtie$ nennyindrawati@unsulbar.ac.id, (D) https://orcid.org/0000-0002-8489-750X

1 Sri Rahayuningsih, Department of Mathematics Education, STKIP YPUP Makassar, South Sulawesi, Indonesia

2 Muhammad Nur Husain, Department of Mathematics Education, STKIP YPUP Makassar, South Sulawesi, Indonesia

3 Nenny Indrawati, Department of Mathematics Education, Universitas Sulawesi Barat, West Sulawesi, Indonesia 
que incluye autoeficacia, creencias y actitudes. Los objetivos de este estudio fueron 1) investigar hasta qué punto la autoeficacia afecta la capacidad de pensamiento creativo matemático de estudiantes; 2 ) descubrir las características de estudiantes que tienen una alta capacidad de pensamiento creativo matemático y una alta autoeficacia. Se empleó un enfoque de método mixto, que combinó la entrevista semiestructurada y el análisis de correlación para investigar el efecto de la autoeficacia en la capacidad de pensamiento creativo matemático del estudiantado. Los sujetos participantes del estudio fueron seleccionados de escuelas secundarias (JHS) que se encuentran en la ciudad de Makassar. Noventa y seis estudiantes (42 niños y 54 niñas, de 14 años) completaron un cuestionario de evaluación de su autoeficacia matemática. En general, los resultados demostraron que la autoeficacia tuvo un efecto en la capacidad de pensamiento creativo matemático de estudiantes de JHS. Además, este estudio reveló que era más probable que estudiantes con alta autoeficacia posean una alta capacidad de pensamiento creativo matemático y viceversa. Las características de estudiantes con alta capacidad de pensamiento creativo matemático y alta autoeficacia incluyen ansiedad excesiva, dependencia de experiencias clave, como la capacidad de generar ideas (novedad cognitiva), la capacidad de proponer diversas soluciones (variedad cognitiva), y la capacidad de cambiar las percepciones (encuadre cognitivo).

Palabras clave: Pensamiento creativo; autoeficacia; novedad cognitiva; variedad cognitiva; encuadre cognitivo.

\section{Resumo (1D)}

Quando se trata de criatividade em matemática, os acadêmicos tendem a se concentrar no âmbito lógico, que inclui fluência, flexibilidade e originalidade, ignorando o valor do reino afetivo, que inclui autoeficácia, crenças e atitudes. Os objetivos deste estudo foram 1) pesquisar até que ponto a autoeficácia afeta a capacidade do pensamento matemático criativo dos estudantes; 2 ) descobrir as características dos estudantes que têm uma alta capacidade de pensamento matemático criativo e alta autoeficácia. Utilizouse uma abordagem de método misto, combinando entrevista semiestruturada e análise de correlação para investigar 0 efeito da autoeficácia na capacidade de pensamento matemático criativo nos estudantes. Os participantes do estudo foram selecionados nas escolas de ensino médio (JHS) localizadas na cidade de Makassar. Noventa e seis alunos (42 meninos e 54 meninas, de 14 anos) preencheram um questionário avaliando sua autoeficácia matemática. No geral, os resultados mostraram que a autoeficácia teve um efeito na capacidade de pensamento matemático criativo dos estudantes do JHS. Além disso, este estudo revelou que estudantes com alta autoeficácia eram mais propensos a possuir alta capacidade de pensamento matemático criativo e vice-versa. Características de estudantes com alta capacidade de pensamento matemático criativo e alta autoeficácia incluem ansiedade excessiva, dependência de experiências-chave, como a capacidade de gerar ideias (novidade cognitiva), a capacidade de propor várias soluções (variedade cognitiva) e a capacidade de mudar percepções (enquadramento cognitivo).

Palavras-chave: pensamento criativo; autoeficácia; novidade cognitiva; variedade cognitiva; enquadramento cognitivo. 


\section{Introduction}

Emotions, attitudes, and beliefs are commonly seen as key determinants of the success of a learning process. In general, the school curriculum, teachers, and formal education infrastructure focus only on cognition in relation to problem solving and problem posing, overlooking the affective components of student learning development (Voica et al., 2020). However, recently many researchers have begun to suggest the need for learning that emphasizes affective and motivational variables (Goldin, 2017).

To focus on this concept, this study uses the affective domain definition of Philipp, (2007). The affective domain covers emotions, beliefs, and attitudes. In general terms, emotion or feeling is attached to an idea or object (Philipp, 2007). Emotion refers to feelings or states of consciousness. There is positive (e.g., the feeling of 'aha') and negative (e.g., the feeling of panic) emotion. Beliefs manifest propositions, understanding and the premises of the world held by individuals. While emotions and beliefs are both considered to be part of the affective domain, they have distinct definitions. Emotions are conscious experiences such as happiness, panic, and so on, whereas belief is a student's belief in something deemed true. Furthermore, attitude refers to the way of behaving, thinking or feeling that indicates one's viewpoint or mentality (Philipp, 2007). More specifically, attitude is the tendency of an individual's state of mind towards a value, which is manifested through the responsive expression of oneself, person, place, object, or event (object of attitude) which ultimately influences individual thoughts and actions (Sewell, 1989). Attitude is strongly associated with social contexts (Moscovici \& Marková, 2006).
The affective domain analyzed in this study is self-efficacy (Bandura, 2010). Self-efficacy can be defined as a person's belief about their ability to meet the challenges in completing a task successfully (Liu et al., 2008). Bandura argues that students with high self-efficacy aspire more in life, be more flexible in problem-solving, demonstrate higher intellectual skills, and conduct self-evaluations more accurately than those of equal cognitive skills, but lack confidence in their abilities (Bandura, 2010). Self-efficacy contributes to the inconsistencies in people's conduct caused by emotions and cognition. Poor performance, low self-esteem and negative conceptions of personal achievement and development are associated with lack of self-efficacy. High self-efficacy results in the ability to recognize one's skills to achieve in particular areas, such as in the academic field. Self-efficacy in the educational field, as a context-related construct, involves individuals' beliefs about their own competence to fulfil the predetermined goals (Vasile et al., 2011).

Self-efficacy has a strong correlation with motivation (Voica et al., 2020). Social environment plays an important role in extrinsic motivation. Extrinsic motivation originates from outside the individual and motivates him to engage in learning activities. For example, someone will study knowing that an exam will be held the following morning with the goal of receiving a good mark or winning a prize. Furthermore, Voica (2020) explains that the key to motivation is energy and strong goal-directed behavior that motivates an individual to take action. Motivation is influenced by the fulfillment of basic demands for survival, welfare, and growth (Güss \& Dörner, 2017). Motivation is an internal process that encourages and directs individuals to engage with the 
environment and solve a problem in an adaptive and open-minded way (Güss \& Dörner, 2017; Rahayuningsih et al., 2021). Motivation levels are reflected in the choice of action as well as the intensity and persistence of the effort (Bandura, 2010). Campbell claims that autonomous motivation is generated from full awareness of the choices made before acting (Campbell, 2008).

Although self-efficacy and motivation are strongly correlated, they differ in some ways. While motivation refers to an individual's desire to achieve a goal, self-efficacy involves believing in one's own ability to create achievements (Gao, 2020). The relationship between the two seems to have a reciprocal effect: increased self-efficacy results in high learning motivation (Chan \& Lam, 2008). The relationship between self-efficacy and motivation may work in the opposite direction to create a cycle of success; when individuals are highly motivated to learn, they tend to achieve their goals and improve self-efficacy (Menon \& Sadler, 2018).

Past studies cover only a small part of mathematical creativity (Bicer et al., 2020), that is creativity in terms of the meaningful insights experienced by students as they learn new concepts (Kaufman \& Beghetto, 2009). Creativity in this study focuses on meaningful interpretations of the experiences, actions, and events that learners have in solving mathematical problems (Levenson, 2013 \& Runco, 1996). Several instructional interventions (e.g., problem posing, open-ended problems, multi-solution assignments) have been proven effective in increasing students' mathematical creativity (Bicer et al., 2020; Leikin \& Elgrably, 2020; Leikin, 2014).

Most researchers have discussed the cognitive domain of mathematical creativity, namely fluency, flexibility, and originality and ignore affective aspects such as self-efficacy, beliefs, and attitudes (Cai \& Leikin, 2020). According to Bandura (2010), the components of creativity in the affective and cognitive domains play an important role in helping students generate new and permanent ideas (Bandura, 2010). Moreover, Gao (2020) argues that creative thinking ability is not sufficient to express one's creativity (creative expression). Creative expression, like other forms of behavior, is influenced by self-judgments of one's ability to produce novelty and useful products (Gao, 2020). Self-judgments is also known as creative self-efficacy (Farmer, 2017), which is the extended form of self-efficacy construction (Bandura, 2010).

Self-efficacy in relation to creative thinking ability has been studied vastly (Gao, 2020; Choi, 2004; Laws, 2002; Farmer, 2017). Research has conceptually and empirically revealed the correlation between self-efficacy and creative thinking ability to express creative expression (expression of ideas, solutions, processes and results). Recently, there has been an increasing need to investigate the relationship between self-efficacy and creative thinking ability. The importance of examining self-efficacy in students may be useful for educators and researchers in facilitating students' creativity (Beghetto, 2006; Byrge \& Tang, 2015). In particular, it will provide beneficial information on factors affecting motivation and learning experience associated with students' self-efficacy and creative thinking ability. Besides, the exploration of the correlation between academic beliefs, behaviors, various levels of self-efficacy and creative thinking ability can contribute to the development of student learning outcomes. Therefore, educators and researchers on creativity will be at a better position in understanding and overcoming factors 
influencing students' sense of eagerness to develop and express creative potentials in themselves. The objectives of the current study involve: 1) investigating the extent to which self-efficacy affects students' mathematical creative thinking ability; 2) exploring the characteristics of students who possess high mathematical creative thinking ability and high self-efficacy.

\section{Methodology}

The effect of self-efficacy on students' mathematical creative thinking ability was investigated through a mixed-methods study, which combined semi-structured interview for data collection and correlation statistics for data analysis (Sharma \& Gigras, 2017). The mixed-methods strategy used in the study was explanatory strategy where the quantitative data analysis was followed by the qualitative data analysis (Creswell, 2012; Fraenkel, et al. 2011).

\section{Participants}

The participants were selected from Junior High Schools in the city of Makassar. They consisted of ninety-six students (42 boys and 54 girls aged around 14 years old). The participants were invited to complete a questionnaire assessing their mathematics self-efficacy. Based on the result of the self-efficacy questionnaire $(\mathrm{M}=56.95$; $\mathrm{SD}=5.97 ; \mathrm{Mdn}=57.00)$, creativity test $(\mathrm{M}$ $=76.43 ; \mathrm{SD}=6.076 ; \mathrm{Mdn}=75.00)$ and student gender, two boys and two girls were chosen to represent students with high creative thinking ability and high self-efficacy in mathematics. Students with high creative thinking possess a score of 95 (SKBK) in creative thinking test and a score of 74 (SSE) in self-efficacy test.

\section{Materials}

\section{Mathematics Self-Efficacy Scale}

The mathematics self-efficacy scale was created in Indonesia using Bandura's (2010) self-efficacy scale construction guidelines. The scale consists of ten items that reflect mathematics tasks of varying degrees of difficulty based on the participants' current mathematics study status. Participants were asked to rate the degree to which they agreed with the self-efficacy statements. They were required to rate their trust in their ability to complete tasks by selecting a number between SE0 (cannot do at all) and SE10 (highly certain can do). Participants' mathematics self-efficacy level were determined by the total score of the ten items. The ten items had a reliability score of 0.95 (Cronbach's $\alpha$ ).

\section{Mathematics Creative Thinking Ability Scale}

The Mathematics Creative Thinking Ability Scale was developed based on the research instrument of Rahayuningsih et al. (2020). It contains an indicator of creative thinking ability that is cognitive flexibility (Singer et al., 2017 \& Rahayuningsih et al. 2020). According to Singer et al., (2017), the context used to examine students' creativity in mathematics involves mathematics tasks, like problem-solving sheets, that can be used as an instrument to measure students' mathematical creative thinking ability. In a problem-solving context, Singer considers cognitive flexibility as the ability to pose a new solution to a problem; it offers various problem-solving strategies, generates novelty in solutions and changes the existing thinking framework. 
Table 1

Indicators of Mathematical Creative Thinking Ability. Adapted from Rahayuningsih. 2020.

\begin{tabular}{|c|c|c|}
\hline No & $\begin{array}{c}\text { Indicators of mathematical creative } \\
\text { thinking ability }\end{array}$ & Operational Definition \\
\hline 1 & cognitive novelty & $\begin{array}{l}\text { Find new strategies in solving a problem } \\
\text { Display a new mindset }\end{array}$ \\
\hline 2 & cognitive variety & $\begin{array}{l}\text { Plan and use a variety of resolution strategies when } \\
\text { faced with complex problems and deadlocks } \\
\text { Change the problem-solving strategy when faced } \\
\text { with deadlocks } \\
\text { Think of different ways to solve the problem } \\
\text { Provide a variety of ways to solve the problem }\end{array}$ \\
\hline 3 & cognitive framing & $\begin{array}{l}\text { Take detailed steps to find a deeper meaning for the } \\
\text { answer or solution to the problem }\end{array}$ \\
\hline
\end{tabular}

Note: derived from research.

\section{Procedures}

The quantitative data analysis involved descriptive and inferential statistics, while the qualitative data analysis was carried out through: 1) Data reduction; 2) Data Display; 3) Conclusion Drawing/Verification (Creswell, 2012; Fraenkel, et al. 2011). Research hypotheses were tested using simple regression analysis. Hypothesis testing was done to investigate the effect of the independent variable (self-efficacy, $\mathrm{X}$ ) on the dependent variable (mathematical creative thinking ability, Y). The statistical hypotheses used in this study included:

$$
\begin{aligned}
& \text { H0 }: \rho \leq 0 \\
& \text { H1 }: \rho>0
\end{aligned}
$$

Note:

Ho : Self-efficacy had no positive effect on students' mathematical creative thinking ability.

H1 : Self-efficacy had a positive effect on students' mathematical creative thinking ability.

Participants who represented the highscore category in the creativity test were invited for semi-structured interview. The participants had to conduct face-to-face interviews individually for 30 to 45 minutes. The interview began with exploring the participant's understanding of confidence in mathematics learning. Each of the participants was asked to reveal what $\mathrm{s} / \mathrm{he}$ was thinking at the moment and associate it with her/his past experience that is relevant to the interview question on problem-solving self-efficacy. The participants were asked to elaborate on their ideas during the interview to provide insightful information for the researcher and familiarize themselves with all of the survey statements.

\section{Findings and Discussion}

To what extent does self-efficacy affect students' mathematical creative thinking ability? 
1 Descriptive Statistics Analysis

\begin{tabular}{|c|c|c|c|c|}
\hline \multicolumn{5}{|c|}{ Descriptive } \\
\hline & & & Statistic & Std. Error \\
\hline \multirow[t]{13}{*}{ Self-efficacy } & Mean & & 56.95 & .614 \\
\hline & 95\% Confidence Interval for Mean & Lower Bound & 55.73 & \\
\hline & & Upper Bound & 58.16 & \\
\hline & $5 \%$ Trimmed Mean & & 56.72 & \\
\hline & Median & & 57.00 & \\
\hline & Variance & & 35.008 & \\
\hline & Std. Deviation & & 5.917 & \\
\hline & Minimum & & 44 & \\
\hline & Maximum & & 74 & \\
\hline & Range & & 30 & \\
\hline & Interquartile Range & & 9 & \\
\hline & Skewness & & .505 & .250 \\
\hline & Kurtosis & & .311 & .495 \\
\hline \multirow{13}{*}{ Creative thinking ability } & Mean & & 76.43 & .630 \\
\hline & 95\% Confidence Interval for Mean & Lower Bound & 75.18 & \\
\hline & & Upper Bound & 77.68 & \\
\hline & $5 \%$ Trimmed Mean & & 76.39 & \\
\hline & Median & & 75.00 & \\
\hline & Variance & & 36.922 & \\
\hline & Std. Deviation & & 6.076 & \\
\hline & Minimum & & 63 & \\
\hline & Maximum & & 95 & \\
\hline & Range & & 32 & \\
\hline & Interquartile Range & & 7 & \\
\hline & Skewness & & .221 & .250 \\
\hline & Kurtosis & & .171 & .495 \\
\hline
\end{tabular}

2 Inferential Statistics Analysis

a Test of Normality

Test of Normality

\begin{tabular}{lccc}
\hline & \multicolumn{3}{c}{ Shapiro-Wilk } \\
& Statistic & df & Sig. \\
Self-efficacy & .975 & 93 & .072 \\
Creative thinking ability & .976 & 93 & .078 \\
\hline
\end{tabular}

Since the sample number was less than 100 , test of normality was conducted using Shapiro-Wilk. The analysis of results showed a statistical value of 0.975 for self-efficacy or $\mathrm{p}$-value $=0.072>0.05$, suggesting normal distribution of data. Meanwhile, creative thinking obtained a statistical value of 0.976 and sig. or p-value $=0.078>0.05$, indicating normal distribution of data. 
b Test of Linearity

\begin{tabular}{lllrrrrr}
\hline & & \multicolumn{2}{c}{ ANOVA Table } & & & \\
\hline & & & $\begin{array}{c}\text { Sum of } \\
\text { Squares }\end{array}$ & df & \multicolumn{1}{c}{$\begin{array}{c}\text { Mean } \\
\text { Square }\end{array}$} & F & Sig. \\
\hline Creative thinking & & & & & \\
ability & & & 2485.776 & 24 & 103.574 & 7.731 & .000 \\
Self-efficacy & & (Combined) & 2019.190 & 1 & 2019.190 & 150.716 & .000 \\
& & Linearity & 466.586 & 23 & 20.286 & 1.514 & .096 \\
& Within Groups & Deviation from Linearity & 911.020 & 68 & 13.397 & & \\
\hline
\end{tabular}

Test of normality based on the ANOVA table showed a statistical value of 150.716 with $p$-value $=0.096>0.05$, therefore $\mathrm{H}_{0}$ was accepted Thus, it can be said that self-efficacy had a linear correlation with creative thinking ability.

c Hypothesis Testing

\begin{tabular}{|c|c|c|c|c|c|c|}
\hline \multicolumn{7}{|c|}{ Coefficients $^{a}$} \\
\hline & \multirow[t]{2}{*}{ Model } & \multicolumn{2}{|c|}{$\begin{array}{l}\text { Non-standardized } \\
\text { Coefficients }\end{array}$} & \multirow{2}{*}{$\begin{array}{c}\text { Standardized } \\
\text { Coefficients } \\
\text { Beta } \\
\end{array}$} & \multirow[t]{2}{*}{$\mathbf{t}$} & \multirow[t]{2}{*}{ Sig. } \\
\hline & & B & Std. Error & & & \\
\hline \multirow[t]{2}{*}{1} & (Constant) & 31.341 & 3.925 & & 7.985 & .000 \\
\hline & Self-efficacy & .792 & .069 & .771 & 11.549 & .000 \\
\hline
\end{tabular}

a. Dependent Variable: Creative thinking ability

The regression equation obtained based on the coefficients table was $\hat{Y}$ $=31,341+0.792 \mathrm{X}$, with a statistical value of 11.549 and a significance or $\mathrm{p}$-value $=$ $0.000<0.05$. These figures indicate that $\mathrm{H}_{0}$ was rejected and $\mathrm{H}_{1}$ was accepted. In conclusion self-efficacy had a positive effect on students' mathematical creative thinking ability.

d Test of Regression Equation Significance

\begin{tabular}{|c|c|c|c|c|c|c|c|c|c|}
\hline \multicolumn{10}{|c|}{ Model Summary } \\
\hline \multirow[t]{2}{*}{ Model } & \multirow[t]{2}{*}{$\mathbf{R}$} & \multirow[t]{2}{*}{ R Square } & \multirow{2}{*}{$\begin{array}{l}\text { Adjusted R } \\
\text { Square }\end{array}$} & \multirow{2}{*}{$\begin{array}{l}\text { Std. Error of the } \\
\text { Estimate }\end{array}$} & \multicolumn{5}{|c|}{ Change Statistics } \\
\hline & & & & & $\begin{array}{l}\text { R Square } \\
\text { Change }\end{array}$ & F Change & df1 & df2 & $\begin{array}{c}\text { Sig. F } \\
\text { Change }\end{array}$ \\
\hline 1 & $.771^{\mathrm{a}}$ & .594 & .590 & 3.891 & .594 & 133.381 & 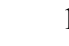 & 91 & .000 \\
\hline
\end{tabular}

a. Predictors: (Constant), Self-efficacy

Analysis based on the model summary table showed a statistical value of 133.381 and $\mathrm{p}$-value $=0.000<0.05$, suggesting to reject $\mathrm{H}_{0}$ and accept $\mathrm{H}_{1}$ It also implied that it was worthwhile to use the regression equation of $\hat{Y}=31.341+0.792 X$. Meanwhile, the correlation between self-efficacy and creative thinking ability was confirmed by an $\mathrm{R}$ value of 0.771 and sig. $=0.000<0.05$. Furthermore, the R-Square value of 0.594 revealed that self-efficacy accounted for $59.4 \%$ of the variance in students' creative thinking ability, with the remaining variables not included in the regression equation.

Descriptive analysis indicated a significant effect of self-efficacy on students' creative thinking ability. Despite this, there are other variables contributing to students' creativity in mathematics, including anxiety, academic ability, learning style and many others. 


\section{The characteristics of students with high mathematical creative thinking ability and high self-efficacy}

The characteristics of students with high creative thinking ability and high self-efficacy in mathematics are revealed through interview excerpts provided below.

Interviewer: How sure are you about your answer?

Participant 1: Even though I originally think there was something wrong with it, I am sure that I can fix it.

Interviewer: Why do you believe that? Participant 1: I figured I'd be able to come up with some different responses, but I'm confident they're all correct; but, on the one hand, I'm curious as to why the answers are so different. The end result should be same.

Interviewer: Tell me how you fixed the problem before you came up with the right solution.

Participant 1: I initially drew a fourunit-area square as the right solution, but after reading the problem several times, I believed I could locate the area of the same form using different shapes, of which there were two, namely a square and a rectangle.

According to the above interview excerpt, the participant seemed to have a lot of confidence in his problem-solving skills. The problem could be solved because he developed the assumption that he was capable of solving it, even though he initially suspected that the problem contained a mistake.

The following interview excerpt proves that when it comes to solving problems, the students can be anxious and cautious.
Interviewer: Why were you so agitated earlier? (while displaying a video recording of the person completing the task) Participant 2: I read the problem many times to ensure that my reading is right.

Interviewer: You're able to say what you're thinking at the time?

Participant 2: I assume the question demands more than one answer, and I'm merely checking that the answer in question is of a different shape. That, I assume, is the remedy. But first, I need to check it for myself.

Interviewer: Is it like that when you look at the camera and seem to be dissatisfied with it?

Participant 2: I'm a bit awkward in front of the camera, which irritates me.

According to the interview excerpt above, the participant solved the problem with extreme caution. The student showed anxiety despite having high levels of self-efficacy and creative thinking skills. Anxiety caused by elements such as fear of being wrong, and constantly convincing himself to answer each question correctly, and acting uncomfortably in front of the camera. The anxiety was evident during the problem-solving process; the student appeared to be excessively cautious, fearful of making a mistake when operating numbers. This finding is in line with those of Hulsizer (2016) who suggests that when students are in front of the camera or hear their own voice, they may become anxious. This shows that they tend to be shy, thereby increasing their anxiety (Huang et al., 2020). However, research conducted by Kearney \& Schuck (2005) shows that making videos causes less anxiety than delivering an oral presentation in a classroom. 
Students' anxiety is also revealed in other interview excerpts, such as presented below.

Interviewer: Several times, you bent your head. This video snippet illustrates it (pointing to the video recording in question).

Participant 3: Yes Mam, I am a bit nervous in front of the camera (while pointing at the camera).

Interviewer: How so?

Participant: I feel like I'm being watched and that is very uncomfortable.

Students with high self-efficacy are more likely to be creative when it comes to solving math problems. This point is confirmed by the following interview excerpt.

Interviewer: Can you tell me whether you were able to figure out your response earlier?

Participant 4: I drew a net of the cube without a lid to locate the area of a flat shape with an area of 4 units, and I think that's a fair answer as well.

Interviewer: Can you show me the sketch? Participant 4: (drawing 4 nets of a different cube without a lid)

Interviewer: Are you sure with your answer?

Participant 4: Yes Mam. I'm pretty sure with it.

Interviewer: Explain why you are so convinced with the answer?

Participant 4: I've given the response a lot of thought, read the questions many times, and double-checked my responses, so I'm confident in my answer.
The above excerpt indicates that besides self-efficacy, metacognitive skills can also affect students' problem-solving ability. The process of metacognition in question is retrospective metacognition, which is metacognition that allows for self-evaluation. According to Özcan \& Eren Gümüş (2019), the only variable which influences mathematical problem-solving efficiency directly was the metacognition experience, which acted as a mediator for the effects of mathematics self-efficacy, mathematics motivation, and mathematics anxiety. A study by Lai et al. (2015) unearthed the fact that metacognition was able to mediate the effect of math anxiety on mathematical problem-solving. However, Zarch \& Kadivar (2006) suggest that mathematical self-efficacy entirely mediates the effect of metacognition on mathematical achievements. In fact, this finding suggests that metacognition plays an essential role in solving challenging tasks, such as mathematical problems (Holton \& Clarke, 2006; Jaafar \& Ayu, 2010; Özsoy, 2011; Rahayuningsih, Sirajuddin, et al., 2021). In addition, it is also believed that metacognition influences performance by controlling behavior using feedback gleaned from student experiences (Moores et al., 2006).

The following section contains a student's interview relating to key experiences associated with the improvement of an open-minded mindset, ability to generate ideas, thinking ability in general, ability to change perceptions as well as an increased toolbox for creativity, curiosity, awareness, and positive attitude.

Interviewer: How did you obtain the answer?

Participant 3: Based on my knowledge of shapes, I define area as the amount of small squares that cover the surface of the shape. 
Interviewer: Will you elaborate?

Participant 3: When viewed from the given task, the area of the flat shape in question is 4 small squares (while showing the picture in the problem). If you have to find other shapes I can make four different shapes (while sketching the shapes in question).

Experts and research conclude that the factors affecting a person's ability to think creatively in mathematics may come from within (internal) and outside (external) students. Internal factors consist of intelligence, talents, interests, attitudes, self-efficacy and motivation; while external factors include environmental conditions, the socioeconomic status of the family and the people around the students such as parents, teachers and peers (Chan \& Lam, 2008; Ikram et al., 2020a; 2020b). According to Bandura (2010), people want to be in control of the events that affect their lives and to see themselves as actors. This feeling of being an actor presents itself in deliberate actions, cognitive processes, and affective processes.

In this study, mathematical self-efficacy involves cognitive and affective processes that guide students to perform better mathematical creative thinking ability. The following are the study's main findings: (1) Most participants became more creative when solving math problems, showing strong self-efficacy; (2) Certain students had relatively high anxiety, but high self-efficacy and mathematical reasoning skills scores; cautious problem-solving allows students to feel anxious; (3) Prior experiences are associated with learning material and an improved way of thought (open mind), the ability to create thoughts, the ability to think in general, the ability to alter attitudes, as well as an expanded creativity toolbox, curiosity, awareness, and a positive mindset.

\section{Conclusions}

In conclusion, the study's findings indicate that students' mathematical self-efficacy impacts their mathematical creative thinking ability at the junior high school level. Other results in this study also show that when students have high self-efficacy, their creative thinking skills improve, and vice versa. Anxiety, reliance on previous experiences, such as the ability to produce ideas (cognitive novelty), the ability to suggest a range of completion procedures (cognitive variety), and the ability to alter expectations (cognitive framing) are traits of students with high mathematical creative thinking abilities and high self-efficacy

\section{Conflict of Interest}

The authors declare no competing interests.

\section{Author contribution statement}

The total contribution percentage for the conceptualization, preparation, and correction of this paper was as follows: S.R 60 $\%$., M.N $30 \%$ and N.I. $10 \%$.

\section{Data availability statement}

The data supporting the results of this study will be made available by the corresponding author, [S.R], upon reasonable request. 


\section{References}

Bandura, A. (2010). Self-efficacy -Bandura. The Corsini Encyclopedia of Psychology, 1-3.

Beghetto, R. A. (2006). Creative self-efficacy: Correlates in middle and secondary students. Creativity Research Journal, 18(4), 447-457. https://doi.org/10.1207/s15326934crj1804_4

Bicer, A., Lee, Y., Perihan, C., Capraro, M. M., \& Capraro, R. M. (2020). Considering mathematical creative self-efficacy with problem posing as a measure of mathematical creativity. Educational Studies in Mathematics, 105(3), 457-485. https://doi.org/10.1007/s10649-020-09995-8

Byrge, C., \& Tang, C. (2015). Embodied creativity training: Effects on creative self-efficacy and creative production. Thinking Skills and Creativity, 16, 51-61. https://doi.org/10.1016/j. tsc.2015.01.002

Cai, J., \& Leikin, R. (2020). Affect in mathematical problem posing: conceptualization, advances, and future directions for research. In Educational Studies in Mathematics (Vol. 105, Issue 3). https://doi.org/10.1007/s10649-020-10008-x

Campbell, C. (December, 2008). Book review: Foucault, psychology and the analytics of power by Hook, Derek. Basingstoke: Palgrave MacMillan, 2007, 16, 1-16. https://doi. org/10.1002/casp.994

Chan, J. C. Y., \& Lam, S. F. (2008). Effects of competition on students' self-efficacy in vicarious learning. British Journal of Educational Psychology, 78(1), 95-108. https://doi. org/10.1348/000709907X185509

Choi, J. N. (2004). Individual and Contextual Predictors of Creative Performance : Creativity Research Journal, $16(2$ \& 3), 187-199.

Creswell, J. W. (2012). Educational research: Planning, conducting, and evaluating quantitative and qualitative research. In Educational Research, 4. https://doi.org/10.1017/ CBO9781107415324.004

Farmer, S. M. (2017). Creative self-efficacy: potential antecedents and relationship to creative performance CREATIVE SELF-EFFICACY : ITS POTENTIAL ANTECEDENTS AND, 45(January 2002), 1137-1148.

Fraenkel, Jack R; Wallen, Norman E; Hyun, H. H. (2011). How to Design Research in Education and Evaluate Research in Education (8th ed) (S. Kiefer (ed.); 8th ed.). McGraw-Hill Education.
Gao, J. (2020). Sources of Mathematics Self-Efficacy in Chinese Students: a Mixed-Method Study with Q-Sorting Procedure. International Journal of Science and Mathematics Education, 18(4), 713-732. https://doi.org/10.1007/ s10763-019-09984-1

Goldin, G. A. (2017). Mathematical creativity and giftedness: perspectives in response. $Z D M$ - Mathematics Education, 49(1), 147-157. https://doi.org/10.1007/s11858-017-0837-9

Güss, C. D. \& Dörner, D. (2017). The importance of motivation and emotion for explaining human cognition. The Behavioral and Brain Sciences, 40, 38-39. https://doi.org/10.1017/ S0140525X17000164

Holton, D., \& Clarke, D. (2006). Scaffolding and metacognition. International Journal of Mathematical Education in Science and Technology, 37(2), 127-143. https://doi. org $/ 10.1080 / 00207390500285818$

Huang, M. C. L., Chou, C. Y., Wu, Y. T., Shih, J. L., Yeh, C. Y. C., Lao, A. C. C., Fong, H., Lin, Y. F., \& Chan, T. W. (2020). Interest-driven video creation for learning mathematics. In Journal of Computers in Education 7(3). Springer Berlin Heidelberg. https://doi.org/10.1007/ s40692-020-00161-w

Hulsizer, H. (2016). Student-produced videos for exam review in mathematics courses. International Journal of Research in Education and Science, 2(2), 271-278. https://doi. org/10.21890/ijres.46577

Ikram, Muhammad, Purwanto, Nengah Parta, I., \& Susanto, H. (2020a). Mathematical reasoning required when students seek the original graph from a derivative graph. Acta Scientiae, 22(6), 45-64. https://doi.org/10.17648/acta. scientiae.5933

Ikram, Muhammad, Purwanto, Parta, I. N., \& Susanto, H. (2020b). Exploring the potential role of reversible reasoning: Cognitive research on inverse function problems in mathematics. Journal for the Education of Gifted Young Scientists, 8(1), 591-611. https://doi. org/10.17478/jegys.665836

Jaafar, W. M. W. \& Ayu, A. F. M. (2010). Mathematics self-efficacy and meta-cognition among university students. Procedia - Social and Behavioral Sciences, 8(December 2013), 519-524. https://doi.org/10.1016/j. sbspro.2010.12.071 
Kaufman, J. C., \& Beghetto, R. A. (2009). Beyond Big and Little: The Four C Model of Creativity. Review of General Psychology, 13(1), 1-12. https://doi.org/10.1037/a0013688

Kearney, M., \& Schuck, S. (2005). Students in the Director's Seat: Teaching and Learning with Student-generated Video. Edmedia, 2864-2871.

Lai, Y., Zhu, X., Chen, Y., \& Li, Y. (2015). Effects of mathematics anxiety and mathematical metacognition on word problem solving in children with and without mathematical learning difficulties. PLOS ONE, 10(6). https://doi. org/10.1371/journal.pone. 0130570

Laws, J. (2002). Self-efficacy beliefs and creative performance in adults: A phenomenological investigation. In National Library of Canada (pp. 1-192).

Leikin, R. (2014). Challenging Mathematics with Multiple Solution Tasks and Mathematical Investigations in Geometry. 59-80. https:// doi.org/10.1007/978-3-319-04993-9_5

Leikin, R., \& Elgrably, H. (2020). Problem posing through investigations for the development and evaluation of proof-related skills and creativity skills of prospective high school mathematics teachers. International Journal of Educational Research, 102(July 2018), 1-13. https://doi.org/10.1016/j.ijer.2019.04.002

Levenson, E. (2013). Tasks that may occasion mathematical creativity: Teachers' choices. Journal of Mathematics Teacher Education, 16(4), 269-291. https://doi.org/10.1007/ s10857-012-9229-9

Liu, C. J., Jack, B. M., \& Chiu, H. L. (2008). Taiwan elementary teachers' views of science teaching self-efficacy and outcome expectations. International Journal of Science and Mathematics Education, 6(1), 19-35. https://doi. org/10.1007/s10763-006-9065-4

Menon, D., \& Sadler, T. D. (2018). Sources of Science Teaching Self-Efficacy for Preservice Elementary Teachers in Science Content Courses. International Journal of Science and Mathematics Education, 16(5), 835-855. https://doi.org/10.1007/s10763-017-9813-7

Moores, T. T., Cha-Jan, J. C., \& Smith, D. K. (2006). Clarifying the Role of Self-Efficacy and Metacognition as Predictors of Performance: Construct Development and Test. Data Base for Advances in Information Systems, 37, 125-132. https://doi. org/10.1145/1161345.1161360
Moscovici, S., \& Marková, I. (2006). The Making of Modern Social Psychology: The Hidden Story of How an International Social Science was Created, 1, 1-296.

Özcan, Z. Ç. \& Eren Gümüş, A. (2019). A modeling study to explain mathematical problem-solving performance through metacognition, self-efficacy, motivation, and anxiety. Australian Journal of Education, 63(1), 116-134. https://doi.org/10.1177/0004944119840073

Özsoy, G. (2011). An investigation of the relationship between metacognition and mathematics achievement. Asia Pacific Education Review, 12(2), 227-235. https://doi.org/10.1007/ s12564-010-9129-6

Philipp, R. (2007). Mathematics teachers' beliefs and affect. Second Handbook of Research on Mathematics Teaching and Learning, 257-315.

Rahayuningsih, S, Hasbi, M., Mulyati, M., \& Nurhusain, M. (2021). The Effect of Self-Regulated Learning on Students' Problem-Solving Abilities. AKSIOMA: Jurnal Program Studi Pendidikan Matematika, 10(2), 927-939. https:// doi.org/10.24127/ajpm.v10i2.3538

Rahayuningsih, S, Sirajuddin, S., \& Ikram, M. (2021). Using Open-ended Problem-solving Tests to Identify Students' Mathematical Creative Thinking Ability. Participatory Educational Research, 8(3), 285-299. https://doi. org/10.17275/per.21.66.8.3

Rahayuningsih, Sri, Sirajuddin, S., \& Nasrun, N. (2020). Cognitive flexibility: exploring students' problem-solving in elementary school mathematics learning. JRAMathEdu (Journal of Research and Advances in Mathematics Education), 6(1), 59-70. https://doi. org/10.23917/jramathedu.v6i1.11630

Runco, M. A. (1996). Personal creativity: Definition and developmental issues. New Directions for Child and Adolescent Development, 1996(72), 3-30. https://doi.org/10.1002/ cd.23219967203

Sewell, W. H. (1989). Some Reflections on the Golden Age of Interdisciplinary Social Psychology. Social Psychology Quarterly, 52(2), 88. https://doi.org/10.2307/2786909

Sharma, S., \& Gigras, Y. (2017). A Survey. 1953, 87-97. https://doi.org/10.4018/978-1-52252154-9.ch006 
Singer, F. M., Voica, C., \& Pelczer, I. (2017). Cognitive styles in posing geometry problems: implications for assessment of mathematical creativity. ZDM - Mathematics Education, 49(1), 37-52. https://doi.org/10.1007/ s11858-016-0820-x

Vasile, C., Marhan, A. M., Singer, F. M., \& Stoicescu, D. (2011). Academic self-efficacy and cognitive load in students. Procedia - Social and Behavioral Sciences, 12(February 2014), 478-482. https://doi.org/10.1016/j. sbspro.2011.02.059
Voica, C., Singer, F. M., \& Stan, E. (2020). How are motivation and self-efficacy interacting in problem-solving and problem-posing? Educational Studies in Mathematics, 105(3), 487-517. https://doi.org/10.1007/ s10649-020-10005-0

Zarch, M. K., \& Kadivar, P. (2006). The role of mathematics self-efficacy and mathematics ability in the structural model of mathematics performance. WSEAS Transactions on Mathematics, 5(6), 713-720.

\section{(9) $(\Theta \Theta \Theta$}

Mathematical Creative Thinking Ability and Self-Efficacy: A Mixed-Methods Study involving Indonesian Students (Sri Rahyuningsih • Muhammad Nurhusain • Nenny Indrawati)

Uniciencia is protected by Attribution-NonCommercial-NoDerivs 3.0

Unported (CC BY-NC-ND 3.0) 